\title{
ME AND TOBA: A CHILDHOOD WORLD IN A BATAK MEMOIR*
}

\author{
Susan Rodgers
}

In many ethnic cultures in Indonesia the time spent growing up is often thought of as a period when individuals move beyond a supposedly incomplete, not fully human state of infancy toward a more orderly time of "truly human" adulthood. Babies are typically viewed as considerably less than full persons, and childhood is the time they become completely human: through learning the adat (Hocal custom"), by coming to discern and interact appropriately with the various types of kinspeople and social classes around them, and--perhaps most centrally--by leaming to speak the local language. A writer's memoirs of his childhood often subtly detail this fundamental process of becoming human while recording the more mundane experiences of growing up. Given this framework, autobiographical accounts in Indonesia often bear on much larger cultural issues.

For youngsters in late colonial times growing up also often meam "becoming a Javanese" or "becoming a Toba Batak" or whatever the local society happened to be. In accord with this, young children were not really full Javanese or Toba, atthough they lived in those societies. They were joined in this unfinished state by foreigners, the insane, and those outside adat and local speech conventions. A proper childhood worked as a door into full Javanese-ness or Toba-ness. Childhood memoirs often narrate an author's passage through such a transition.

Dr. H. Ruslan Abdulgani, formerly minister of information and minister of foreign affairs as well as Indonesia's ambassador to the UN, includes a passage in his autobiography that expertly weaves together all these themes of maturation, personhood, speech, etiquette, and ethnic "completeness." The first chapter of his autobiography is entited "My Childhood World"' and portrays the bustling, socially variegated kampung (neighborhood, in this case) called Plampitan in Surabaya where his family lived. They owned a provisions shop, and the time was about 1918. He writes about growing up, and relates the type of advice his mother would give her children:

* I would like to thank William Frederick of Ohio University's History Department and Dr. P. Voorhoeve for reading an earty draft of this paper. Professor Nalom Siahaan, recently retired from the literature faculty of Universitas Indonesia, also provided valuable help. My chief thanks, however, go to P. S. Naipospos, the author of Aku dan Toba, who generoushy shared information on his life and writing career with me through letters as I was drafting this article.

1. Edited and translated by William H. Frederick, Indonesia 17 (April 1974): 112-35. Anthomy Reid's "On the Importance of Autobiography" (Indonesia 13 [April 1972]: 1-4) and the essays that follow it discuss the translation and historical analysis of such personal history material. G. W. J. Drewes summarizes several memoirs, including Aku dan Toba, in his "Autobiografieën van Indonesiers," Bijdragen tot de Taal-, Land- en Volkenkunde 107 (1951): 226-64. 
All through $m y$ childhood, and even later, when as an adult I held various positions in the government, Mother reminded me of three duties: when you meet someone or come to a crossroads, don't forget to say "Peace be with you" (Assalam alaikum), even if you just murmur it to yourseff; don't look up to the powerful and rich without at the same time looking down at the ordinary folk (rakyat) and considering their needs; and always remember God. Once I asked my mother where God was. She smiled at me and whispered, IIn your heart! That is why you must never forget Him."

Mother also asked that, after we were grown up and independent, we children remember to be sing Jowo, which translates roughly as "Javanese in thought" or simply "truly Javanese." By giving us a number of examples, Mother made clear that "sing Jowo" meant being polite, friendly and open towards others, cooperative, helpful, and so forth. All this was especially important when it came to the relationship between children and their parents, and in this regard "sing Jowo" also meant to be helpful to parents, to support them when they were no longer able to do so themselves, and to give them tender loving care. 1 often heard $\mathrm{my}$ mother discussing with some of her friends the sad stories of certain children they knew who, although they had risen in society and were doing well, paid no attention to their parents. They were called ndak Jowo, which literally meant "not Javanese." (The same term was often used by kampung people in a somewhat different sense, meaning "crazy" (gila) or "cracked" (sinting).)

It may be a little confusing to someone who didn't grow up with it, but I should explain that similar words were used to describe something rather different. Small children who weren't yet old enough to understand the danger of fire, sharp knives, broken glass, and the like, were considered durung Jowo, literally "not yet Javanese." Children who were a bit older but were still ill-behaved, who picked on their brothers and sisters for example, were also said to be "durung Jowo." On the other hand, the child who got along well with his family, did good deeds for his grandparents, and helped his mother, was described as being wis Jowo, which means that he understood how to behave property as a member of a Javanese family. ${ }^{2}$

It is clear from other sections of his memoir that Abdulgani also saw his childhood as a time when he grew into Indonesian national consciousness. As a small boy, not surprisingly, he tended to see people from other Indonesian ethnic societies as inferior to the Javanese, and his mother identified resistance against the Dutch and any eventual revolution against them as a strictly Javanese affair, which would result in a restored Javanese society. By the end of his childhood, however, Abduilgani had come to discover the social worth of other Indonesian peoples and their common historical experiences of oppression by the colonial state. He had begun to see the value of bahasa Indonesia, and of the world beyond Java.

In their memoirs, such writers as Abdulgani blend images of personal grouth and childhood with those of societal development (maturation") and histony. In fact, it is probably not too much to say that many authors of Abdulgani's generation cannot write about Indonesia and histony without drawing on the same storehouse

2. Abdulgani, My Childhood World," p. 119. 
of symbols that they use to write about the child's experiences of growing up into a social world.

Because of their relationship with these larger cultural issues, published childhood memoirs are extraordinarily important texts for anthropologists and historians of Indonesia. In this article I would like to examine a relatively little-known memoir by a Toba Batak named "P. Pospos." Written in Jakarta in 1948 when the author was twenty-nine, it was first published by Balai Pustaka in $19500^{3}$ The book is entitled Aku dan Toba: Tjatatan dari masa kanak2 [Me and Toba: Notes from Childhood]. The memoir chronicles a boy's acquisition of the knowledge and speech needed to live in the social world of adults specifically in Dutch-controlled Tapanulit in the 1920 s and '30s. So, Pospos's growth to adulthood is not just his development into a full Toba Batak in the sense set out above but is also his transformation into a young man adept at living in the colonial world.

There is considerable historical interest in this aspect of the memoir but my focus will be somewhat different: I deal primarily with the communication styles used in the book. This topic also concerns transitions, from Batak oral culture to mass literacy. This transition shapes the way Pospos presents his earty life.

The first edition of the memoir runs to $827^{7} \times 4^{3} / 4^{\prime \prime}$ pages..$^{5}$ it is written entirely in Indonesian, not Toba Batak (a separate language not intelligible to people who speak only Indonesian). Although the book does contain a few Toba-language kinship terms of address and some adat proverbs, these are immediately translated

3. Balai Pustaka issued a second edition of the book in 1967. Although the author's full name is Paian Sihar Naipospos, the child in the memoir is given the first name Djohanis; no explanation is given for this discrepancy. I learned of Pospos's full name from a note he wrote on July 15, 1987, which was enclosed in a letter to me (dated July 22, 1987) from Professor Nalom Siahaan. According to Professor Siahaan, Naipospos was born on October 9, 1919, in North Tapanuli.

4. Tapanuli refers to the central Batak region around Lake Toba; today the subprovince of North Tapanuli is roughly coterminous with the Toba area while South Tapanuli includes Angkola (or Angkola-Sipirok) and Mandailing. Ethnic boundaries shift a good deal among Batak but in one common view there are seven Batak peoples: Toba, Simelungun, Karo, Pakpak, Dairi, Angkola or Angkola-Spiprok, and Mandailing. Some people add Silindung, while some say Karo and/or Mandailing are not Batak. See Rita S. Kipp and Richard Kipp, eds., Beyond Semosir: Recent Studies of the Batak of Sumatra, Ohio University Papers in Intemational Studies, SE Asia Series (Athens, Ohio, 1983) for anthropological discussions of comtemporary Batak social structure; T. P. Siagian's "A Bibliography of the Batak Peoples" (Indonesia 1 [April 1966]: 161-84) provides a valuable list of publications on the different Batak groups. A basic adat law source on the Toba Batak is J. C. Vergouwen's The Social Organisation and Customary Law of the Toba-Batak or Northem Sumatra, Koninklijk Instituut voor Taal-, Land, en Volkenkunde Translation Series No. 7 (The Hague: Nijhoff, 1964, originally published in 1933 as Het Rechtsleven der Tobo-Bataks). See also the extensive research on Toba social change by anthropologist Edward $M$. Bruner (especially "Kin and Non-Kon," in Urban Anthropology, ed. A Southall [Oxford: Oxford University Press, 1973), pp. 373-92).

Ny own fiekdwork has not been in Toba but in the Sipirok area; for discussions of the impact of literacy there, see my Orality, Literacy, and Batak Concepts of Marriage Alliance," Journal of Anthropological Research 40, 3 (Fall 1984): 433-50, and "A Batak Literature of Modemization," Indonesia 31 (April 1981): 137-61.

5. The second edition runs to 132 smaller $\left(6^{1} / 2^{1} \times 4^{1} / 2^{11}\right)$ pages. 
into Indonesian, so that the narrative is accessible to a multiethnic reading audience throughout Indonesia. Thus, writing and publishing the book in Jakarta, Pospos chose to address a reading audience outside the Toba Batak area. ${ }^{6}$ Nor was his book meant to be recited orally in any of the numerous comversational and oratorical styles ${ }^{7}$ available to Toba Batak men of his generation.

Pospos grèw up at a time of swift transition, when Toba moved from being an oral culture with restricted, runic sorts of writing to becoming one of indonesia's more literate and even "school-minded" areas by the 1950s. My main aim will be to try to locate $M e$ and Toba within this oral-culture-to-literacy context, and to explore some of the ways in which the book's dual ties to a Toba oral heritage and to Indonesian-language commercial print publication have shaped Pospos's portrayal of his childhood world.

Tapanuli has no sharp distinction between such broadly drawn categories as traditional village oral culture" or "urban literate culture." Communication forms interpenetrate and mutually define each other. This was true in late colonial times as well as today. Ritual speech styles used in adat ceremonies, for instance, have not disappeared in the face of mass literacy in the Batak and Indonesian languages. Rather, they have often been reshaped under literacy's influence, to emerge sometimes as printed Holklore texts. At other times they have incorporated stylistic devices borrowed from writing. In addition, oral forms such as tarombo clan genealogies continue to imfluence the printed culture, shaping the way that history is written and publicly validated. Me and Toba emerged from this confluence of oral and print styles. To interpret the memoir simply as a product of national-level print and publication culture would miss its undoubted ties to Toba's robust oral heritage. At the same time, it would be a mistake to overemphasize the oral residue shaping the book's narrative styles and content. In some of its features the memoir is a

6. In a letter to me dated August 22, 1987, Naipospos notes that most Batak young people who had received further education in 1950 had studied outside Tapanuli, and also that the children of Batak migrants in Java did not know the Batak language. He says that he chose to use Indonesian and not Batak because he hoped that Batak young people living in cities would be able to read the book, which he conceptualized as a set of experiences that might provide young people with guidance in growing up.

7. See Vergouwen, Social Organisation, for basic information in English translation on Toba oratory. For bibliographical information see the Batak languages entry in P. Voorhoeve, Critical Survey of Studies on the Languages of Sumatra (The Hague: Nijhoff, 1955). For published handbooks of Toba oratory and adat by Toba Batak, see, for instance, H. B. Siahaan, Patik dohot oehoem ni halak Batak; na sinoerathon djala pinatoere ni H. B. Siahaan gelar Mangaradja Asal Balige" (Laguboti: ZendingsDrukkerij, 1938-1939); W. M. Hoetagaloeng, "Paestaha taringot toe tarombo ni bangso Batak," rangkoman 1 (Laguboti: Zendings-Drukkerij, 1926); M. Salomo Pasariboe, "Barita ni Siboroe Deak paroedjar (Moela ni djolma dohot tano): (Sibolga: Manullang, 1925); H. B. Siahaan, Tamba-tamba ni oempama ni halak-Batak; sitoloe-sada-ihot songon tiang ni langgatan (Tarutung: Silindung Drukkerij, 1937); and Mangaradja Salomo gelar Patoean Sarangnadiborngin, Tarombo Borbor-morsada" (Balige: Hacenatos, 1938). H. N. van der Tuuk's 1860 volume on Toba speech in his Bataksch Leesboek series (Stukken in het Tobasch, vol. 1 of the series atso covering Mandailing and Dairi) is one of the most extensive and certainly earliest sources, recorded by the Dutch linguist from Batak informants. 
product of an unusually thoroughgoing print culture, when the book is compared to other works by Batak authors published in the 1920 s to 1950 s period. ${ }^{8}$

To me the book appears to be an unusually powerful and evocative work, not marred by the sentimentalized nostalgia for traditional Batak village culture that became prominent in some Medan newspaper writing of the late 1970s and ' 80 s as print literacy was used to promote Batak ethnic culture in a national arena dominated by the Javanese. Part of the book's charm lies in its ties to both orality and lineracy and its ambiguous position between the two. The book describes Pospos's transition from being a small child in a Toba village living in an impoverished, lower-class household to being at the end of the memoir a literate young man of about 18, with a MULO ${ }^{9}$ education behind him, setting off in a ship from the port at Belawan to continue his schooling in colonial Java. Along the way Pospos the writer portrays Pospos the child moving from an oral Toba Batak world to a school world where the successful student spoke and, especially, wrote in Dutch, "bahasa Melayu," and even German and English. Growing up meam growing into textual studies, in outsiders' languages. From the vantage point of postrevolutionary Indonesia, Pospos depicts this transition with irony and a touch of self-mockery.

Recent research by anthropologists, linguists, literature specialists, historians, and philosophers on the impact of literacy in traditional cultures is valuable in interpreting the various marrative structures, word choices, content, and page format in Me and Toba. ${ }^{10}$ Later in the article 1 shall look at a number of examples from

8. Another range of Batak writers such as Armijn Pane (from a Sipirok family) deliberately wrote about pan-Indonesian concerns in an effort to create a national Indonesian-language literature. This focus differentiates them from authors like Pospos and the adat handbook writers, who take Batak nural life in Tapanuli as their main theme.

9. MULO stands for Meer Uitgebreide Lagere Ondenwijs, and indicates a kind of junior high school, but one of high standing because it made linking up with the Dutch system possible.

10. Among the most useful studies as background to this essay are Watter J. Ong's Orality and Literacy: The Technologizing of the Word (London and New York: Methuen, 1982) and his Rhetoric, Romance and Technology (Ithaca: Cornell University Press, 1971). See also Amin Sweeney, Authors and Audiences in Traditional Malay Literature, University of California at Berkeley, Center for South and Southeast Asia Studies Monograph Series No. 20 (Berkeley, 1980); and Deborah Tannen, ed., Spoken and Written Language: Exploring Orality and Literacy, Advances in Discourse Processes Series (Nonwood, NJ: Ablex, 1982). This last anthology is especially strong in its attention to the mutual effects of spoken styles and written styles, as they reshape each other. Also insightful are Jack Goody, The Domestication of the Savage Mind (Cambridge, England: Cambridge University Press, 1972); Jack Goody, ed., Literacy in Traditional Societies (Cambridge, England: Cambridge University Press, 1968); S. Scribner and M. Cole, The Psychology of Literacy (Cambridge, Mass.: Havard University Press, 1981); and D. Olson, N. Torrance, and A. Hildyard, eds., Literacy, Language, and Learning (Cambridge, England: Cambridge University Press, 1985). This last book has a valuable annotated bibliography on research on the transition to literacy compiled by Ron Scollon (pp. 412-26). Finally, Amin Sweeney's Reputations Live On: An Early Malay Autobiography (Berkeley and Los Angeles: University of California Press, 1980) includes insightful comments on the continued importance of oratorical styles and audience expectations in shaping a written Malay autobiography. 
the book in light of this research but will begin with a short description of the history of writing and print in the Batak cultures.

\section{The Transition to Print Literacy in Tapanuli}

All of the Batak cultures apparently had Sanskrit-based syllabic writing systems, ${ }^{11}$ probably derived from the south or west Sumatran courts. However, only a small elite group could read and write (better, decipher) this system. The old Batak letters served as runic scripts for divination, augury, and healing purposes for the priests who worked for village chiefs. Secret words, spell recipes, and astrological charts were incised on bone, bamboo, and barkbooks, the latter folded up into little bound packets that priests would carry as part of their armamentarium of "power objects." Indeed, objects with Batak letters incised on them were apparently holy, sharing in some of the power of the priest who owned them. The priest himself used the Batak letters primarily as a means to "unlock" powerful oral speeches and spells, and villagers would consult him for access to his secret lore in times of illness or uncertainty about the future. Occasionally andung mourning chants or outlines for clan genealogical narratives were incised onto bark or bamboo in old Batak letters, but the script was never commonly used as a medium of mass literacy.

In the 1820 s Padri followers from the Minangkabau region introduced Arabic script used for copying and recitation of the Koran and prayers into Angkola and Mandailing, to the south of Toba. Like the Batak letters, however, the Arabic script too became primarily a tool to unlock oral worlds. Spellcasters and healers (datu) did use what they thought were the Arabic letters in special sorts of written spells, but Arabic never became a means of mass literacy in the area from Tarutung north to the Toba border with Simelungun. Nor did Islam ever penetrate northward into Toba in any significant way so that Arabic was never an important script there. Through German missionary influence Toba began to convert to Protestant Christianity in the late nineteenth century. The German and Dutch mission schools eventually brought more widespread literacy in a flexible writing system capable of storing and creating innovative messages to the southern Batak societies and Toba. These schools were first introduced in the Sipirok region of Angkola in the 1850s and spread thereafter to other parts of Angkola and Toba. Some early missionaries stayed on in the Sipirok region and developed a strong school system there, but others such as I. Nommensen (the most famous missionary to the Batak) and his followers decided that Islam was already too strong in the southern regions, so they pushed northward into Toba. Major instruments of proselytization were the mission schools, mostly at the primary level, which concentrated on Bible reading and training village religious teachers. In the earty mission years children were taught to read and write using the Batak script, on blackboard and paper. Some school primers, storybooks, and the Bible were printed in the Batak script in the Netherlands for use in Tapanuli.

The Batak script was also used as a medium of instruction for some classes in the early years of the government-run system of primary schools. By the turn of the century, however, lessons in Batak script had largely been replaced by instruction in the Roman alphabet. This was inue throughout the entire government school system in Toba. The Roman alphabet was the predominant medium for introducing the Batak to the familiar European secular curriculum: mathematics, geography,

11. Van der Tuuk's 1860 Bataksch Leesbook, vol. 1, provides examples of Toba texts written in the script. 
European history, Dutch grammar, and foreign language study (that is, Malay, German, and English).

By the 1920 s the Batak rural tano (ethnic, "aboriginal home regions) were sprinkled with various kinds of schoolhouses: sikola metmet (Toba for "little school," covering grades 1-2-3, with Toba Batak as the language of instruction); sikola panonga (grades 4-5-6, "middle school," also using Toba); HIS (Hollandsch Inlandsche Scholen, primary schools with a European curriculum, taught partly in Dutch); various vocational schools such as nurses' training institutes and technical schools for boys; and MULO, for boys and girls who had hopes of going on to other higher, Dutch-language schools in Medan or Java. Successful Batak students sometimes also went on (from MULO, HIS, or in exceptional circumstances, from public elementary school) to the Dutchlanguage Kweekschools or teacher-training institutes in Kota Raja (Banda Aceh) or Bukittinggi. Other students went to the somewhat less-prestigious Normal school in Pemantang Siantar.

Other, even more successful students went on to AMS (Algemeene Middelbare Scholen) and eventually to tertiary education in Java. Academic degrees from the secondary schools were used by Toba, Angkola, and Mandailing as tickets to high-status salaried jobs as teachers, low-level officials or clerks in the colonial bureaucracies, or as clerks in the East Coast plantations in Deli. Securing such jobs carried immense prestige for both the applicant and his family back home in Tapanuli.

With their quickly acquired form of alphabetic literacy, the Tapanuli schools became politically important avenues around the traditional social class system for Batak of commoner or even slave-descendant status. This was so despite some preferential treatment given to the children of chiefly lineages who were cooperative with the Dutch (children of such families reportedly had an easier time gaining entrance to HIS and MULO than did other children).

Pospos was a child during this period when schools were being defined as the main turnstile for poor families to "escape" the rice-farming villages for high-prestige salaried work in bureaucratic settings.

\section{A Précis of Me and Toba}

The undergirding theme of Pospos's memoir is the remembered child's dogged progress through the various levels of the colonial-era school system in North Tapanuli, from sikola metmet in his home village to the NULO in Tarutung, and from there to the boat at Belawan to school in Java.

This joumey through the schools provides the author with his major framework for presenting his early ife. In other words, he writes about getting older in terms of school graduations and degrees, and he discusses the periods of his early life in terms of when he was of "sikola metmet age," "MULO age," and so on.

Chapter 1, which like the others is headed only by a Roman numeral, is typical of the memoir as a whole in its comfortable, easy-going tone and its use of the first person. Characteristically, too, the author persistently refuses to take himseff too seriously. In this chapter, however, Pospos takes special care to translate and elucidate Toba Batak terms, going so far as to use an extensive footnote for one of them. He also takes more care than usual to explain Toba customs in terms intelligible to other Indonesians. In $\mathrm{my}$ translation of this chapter $\mathrm{I}$ have tried to retain much of Pospos's original punctuation and his use of parentheses. (For instance, he will sometimes write the Toba word for father, following it with the Indonesian word in parentheses.) The place names in the chapter refer to little market towns near Lake Toba. 
1

The day was still cool and indeed it was very chilly and fresh every morning in Toba. Usually we children would search out the warmth of a fire in the yard, since almost every morning someone would be burning refuse for fertilizer. But this morning I sat warming myself by the hearth, cooking. My little sibling was still sleeping, while mother was sitting weaving a mat near the door where it was lighter. My father had gone out with our buffalo cart, carrying around other people's merchandise for sale. Three times a week he did that, Friday to the Balige market, Saturday to the Sigumpar market, and Wednesday to the Porsea market. This was our livelihood, in addition to rice we got from the paddies.

Our house was a balebale." From the type of our house you could tell that we were not rich people. Our house was all blackish inside, because of the smoke. In the upper corner hung a basket, saved as a souvenir by $m y$ father. From other people I heard that $m y$ father had mangallung (carried merchandise for sale on his shoulders to Pematang Siantar) in his youth and as a reminder of that time he had hung up the basket.

My father was an elder at church, more or less an assistant Gospel teacher. This position was called sintua in our region and because of this position he did not have to pay the obligatory tax of Rp. 6.60 per year. Maybe this is the reason why lots of people sought this title. My father had been sintua a long time so that sintua was now considered as part of his name. When people called him, it wasn't just his name that was said anymore, it had become St. Ananias.

There was a certain oddity in our region, which was that the names of father, mother, maternal uncle, grandparent, and so on were taboo, that is, we were not allowed to pronounce their names, and this was why it was not until we were grown that we knew the names of our father, our mother, or our grandparents. In fact fights often occurred over the names, when another child dared pronounce the name of our father.

Once the following incident took place. A child was punched by another child and to take revenge the child who had been punched threatened to say the name of the other child's father. Should I say,

* That is, no more than a hut on four poles. Its walls were beaten bamboo and its roof paddy stalks (the roof was changed every year so it wouldn't get holes in it). The other sorts of houses were sopo and ruma, which were much larger and more beautiful, the houses of rich people. The ruma for instance had eight pillars. Its walls were carved boards and its roof was black sugar palm fiber. These houses had just one room, and there people would eat, sleep, and receive guests. The pillars were very tall, so that the space underneath the house could be used as a pen for livestock--so it was "fragrant" underneath the house.

Besides these types of houses there was another new type, which is usually called emper (verandah). Its structure resembles the sorts of houses we see in large numbers in the city. In our coumtry this type house was often given a verandah. 
should I say the name of our father?" Finally he couldn't hold back amy longer, and he cried out: "Betuel." But what's indecent in that? The name was in fact that of his own father, so we all scoffed at him. A fight would also occur, if one child said to another child: "Ee, P've said the name of your father to myself in my heart."

While I was standing on the hearth in from of the fire 1 heard a voice from below, from the fromt yard: "Sintua, sintua!"

The person calling was our teacher, the village school teacher and our Gospel teacher every Sunday.

"He's already left, guru. He has just gone," answered my mother from up above.

After hearing that $m y$ father had left, the teacher said: If that's the case, inang (mother), you'd better give my message to sintua, that si Djohanis (that is, me myself) should be sent to school, because he's already six years old." off home.

"Fine, amang (father)," said my mother, and then the teacher went

My thoughts were still directed towards the pot boiling in front of me, so this corversation wasn't clear to me. I was already used to cooking at home, atthough I was onty six. We village children were taught very quickly to help our parents in things like cooking, looking for firewood, fetching water, and so on.

This activity was not veny hard, because the way village people cooked was very simple. To cook rice for instance, water was first heated up in a pot. After the water was hot, rice was put in the pot and then left until the water came to a boil. Then the water was stirred with a spoon and the amount gauged so that the rice water left wasn't too much and wasn't too little. This was so that the rice wouldn't be too soft and wouldn't be too hard.

Fish was usually just roasted over the fire, and what about cooking the greens? Cassava leaves would be finely pounded, and then placed in a skillet with heated water. Later the leaves would be seasoned with a bit of salt and left to simmer until done.

Indeed, it was very useful that we children could already cook. Parents were usually away from home and it was night before they retumed. My mother for instance went to market every day to sell mobe (a kind of fruit used to preserve fish). She'd go as far as Porsea, Balige, and Sigumpar to sell the mobe and on foot too, although sometimes her profit was no more than twenty-five cents.

I spooned out the boiling water from the pot with a coconut shell spoon. After I had left a little water there, I damped down the fire and lit one again in another hearth, to cook the greens. But my mother said: "Djohanis, it's best that you bathe or wash your face at the well. After that put on that clean shirt of yours. Teacher has come to say that you are now old enough to go to school, so get along to school now. I'll cook those greens myself later."

For a long time I had longed to go to school, since for us children going to school meant "being promoted." Wouldn't we too be able to join in talking about school, and no longer just sit listening with our 
mouths agape, when friends told stories about school? We children would often estimate our ages, to see if we were old enough to go to school. In our circle there was one general method of measuring ages, because there was no understanding among us whatsoever of days, months, and years. A child would be told for instance to stand straight up and. then to put his hand up as straight as he could, and to wrap it around his head. Then it would be seen if the tip of his finger could touch his earlobe on the other side. If it could, that was a sign that he was old enough to go to school. I had myself just been tested this way a few days ago, but the tip of my finger had only just brushed my earlobe.

Even though I was happy to attend school, the news came so suddenly it startled me for a moment. But not long afterward, I ran off to get washed at the well. After eating a little and changing my clothes, off I went to school with my friends who were already used to going there.

The schoolhouse wasn't far from our house. It could even be said that the schoolyard was just in back of our house. Our back border was just a clump of bamboo as a fence and then there was a big road and then the fence to the schoolyard.

My heart went thump-bump at going to school, my fear mixed with joy. All this time I had heard my friends' stories about school, and I had often looked in from outside, while the students were studying in there. But now I wanted to view the school not just from outside, but from inside. Might going to school bring happiness?

This was the question that filled my head while I awaited the great moment. The bell had already rung, the students had already long since gone in to study, but we new would-be pupils were still only allowed to play in the yard. I waited and waited for us too to be called inside, to start school.

That day we did not attend school. We were only allowed to play in the schoolyard and when it was time to go home we too were told by the Head Teacher to go home. He said, only tomorrow would we start. This disappointed me. All my hopes and dreams about school, and my joy when leaving the house earlier in the morning, vanished entirely. I went home dejected.

This first experience 1 found bitter and the next day 1 did not want to go to school amymore. My father repeatedly ordered me to go, but I was reluctamt to do so. Finally my father threatened me with a beating if 1 didn't go, but even that didn't work. Then my father slung me over his shoulder and carried me to school. I sobbed, struggling to free myself, but no matter what I tried my father just kept carting me over his shoulder toward the schoolyard. There he put me down, moaning and groaning. Other friends crowded around me, looking at the spectacle.

Imagine $m y$ embarrassment in front of $m y$ friends. If 1 had been able to face up to my father then, surely 1 would have attacked him. But how in the world could a child of six hope to fight a grown adult? After that time I was no longer brave enough to play truant. I was afraid of $\mathrm{my}$ father and embarrassed in from of $\mathrm{my}$ friends. It could be said that I was among the most hard-working students after that. (Pp. 5-11, in the 1967 edition.) 
The rest of the book goes on to demonstrate just how industrious and diligent (rajin) the narrator remembers himself being as he advanced from one grade to the mext. He takes a somewhat umorthodox, poor man's route to MULO bypassing HIS and taking just enough Dutch lessons in the "wild schoots" to pass the MULO entrance exams.12 A MULO degree, and especially the acceptance letter for further schooling in Jakartà, represented a huge success for a non-aristocratic Toba village boy, but the memoir portrays Pospos as in fact having been somewhat befuddled and directionless in his school career. The narrator never seems to know if he will graduate from his current school, or where he will go if he does pass the final exams. He never knows if his father will provide funds for him to go to the next school, and he has no idea what kind of position he will eventually secure in the colonial Indies once he has finally finished his schooling.

As noted, Pospos relates many of his school endeavors with gentle self-mockery. But he is sharply sarcastic about the Dutch schoolmasters and the Toba families and school personnel who promoted a system of status in the schools that defined personal worth in terms of the type of school a child attended and the kind of degree he obtained. The author portrays many of his young classmates as willing and knowledgeable participants in this scramble for the "right" schools and the "best" degrees.

Several other topics recur throughout the book: the boy's father keeps changing jobs and never seems really to succeed at any endeavor; Pospos himseff as a boy is devilish and hard to instruct, but he generally emerges as one of the two or three brightest children in class (his forte is math and rote memorization, while Dutch comversation is his weakness); his father and mother are never physically or emotionally close to him although his father always finances his educational endeavors; ${ }^{13}$ Dutch civil servants are ridiculous buffoons and some of the Dutch-speaking Batak teachers are their sycophants; some teachers are adept and knowledgeable while some are slow and ignoramt; and girls become fascinating to boys of about MULO age (or HIS age if their schooling has been delayed).

Beyond this no one really knows how far he or she will manage to rise in the Indies' complex, hierarchically ranked school system, or what it will all mean when graduation comes. If graduation comes. The final exams which all the pupils must take after each level of school loom ominously over their lessons. The individual chapters generally proceed in a concrete fashion relating specific school and family events, conversations, and impressions of such things as food, games, arguments, and tests. Often a chapter will initially focus on a topic such as a new grade in school and then veer imto several other issues, eventually returning to the original focus.

12. In his autobiographical note (July 15, 1987), Mr. Naipospos writes that he attended a non-Dutch language primary school for six years (studying also at night) and a Schakelschool (a primary school with Dutch as the language of instruction) for three years, before becoming a pupil at a Christian MULO school in Tarutung for three years. Professor Siahaan adds that after this Naipospos began studies at the MLS (Middelbare Landbouw School) in Bogor, but was unable to complete his course there because the Japanese occupation intervened. (Letter of July 22, 1987.)

13. In his August 22 letter, Pospos states that he wrote his book in part to advise parents to avoid such coolness with their small children. 
The Oral and Literate Context

Seen in the context of other Batak printed texts, Me and Toba is remarkable for its deep textual quality and its reliance on the format and philosophy of commercial primt publishing. The very fact that Pospos is offering "a life" to the public in his book would have been largely unimaginable in a Batak oral world before mass print literacy. Villages could have genealogical chronicles and lineages and clans had origin stories, but individual persons like Pospos could not have significant, separate, individualized lives worth public notice in an oral world. The person as a distinct individual, in fact, was apparently largely absent in the public discourse of preliterate Batak culture. Pospos's book runs counter to this older, village-based world of social categories without recordable separate personalities: the memoir chronicles the quirky, historically situated experiences of one particular Toba boy from one particular family in one particular period of time, all told with an ironic slant that implicitly encourages the reader to question the assumptions of Toba social life. The oral culture would have found such a life both unimaginable and quickly forgettable, since there were no ready genres for presenving experiences and persons that fell so far from the stereotypical imagen of village humanness. Moreover, people from poor families like Pospos's were largely excluded from the overt folk ideology of Toba society, since the oratory was mainly a paean to the social structure of the upper class.

Print reverses the situation. And, since in this case the memoir is written in Indonesian, the story of the small boy can be passed not only to all members of his home society but also to mamy other ethnic groups. This interethnic audience yields a different view of Toba life than we would get had Pospos been writing strictly for other Toba or (a somewhat different case) for Batak of other sub-societies like the Angkola. In the process of turning the author's life into a commercial product the story has to be made to appeal to a certain market, competing for "reader imterest" with life stories from other Indonesian ethnic groups and with short stories, novels, serialized novels in newspapers, and nonfiction.

The 1950 edition of $M e$ and Toba includes a two-page advertisement for other Balai Pustaka books of the season that well illustrates this (following p. 82). The notice announces that sixteen Balai Pustaka books were published in October 1950 (prices listed), including Beberapa Penjakit Chatulistiwa [Several Equatorial Illnesses] by Dr. St. Z. A. Abidin; Partai Buruh [The Labor Party] by C. R. Attlee; Dongeng2 Sulawesi Selatan [Folktales from South Sulawesi] by M. Radjab; Radjawali by Zuber Uslam (children's stories), Nasionalisme dalam Politik Internasional [Nationalism in International Politics] by E. H. Carr; and even Pemeriksaan Dokter Sobelum Kawin [The Doctor's Premarital Exam] by Dr. R. A. Seno Sastroamidjojo. The advertisement concludes by announcing that these books "can be purchased at every bookstore." Pospos's life becomes one book among mamy for the customer's consideration.

The use of photographs in the book is interesting, and somewhat puzzling. Neither edition includes a photograph of the author. Other photographs do, however, appear: both editions use a faded photograph of Lake Toba on their front covers, although the memoir rarely refers to the lake and makes no specific mention of any picture. The 1950 edition of the book has no other illustrations but the second edition includes two additional haff-page plates: an indistinct picture captioned Hotel Prapat, a vacation hotel. Can be used as a place for Government guests" (p. 74), and an ill-reproduced photograph of the entry gate in the same lakeside town (p. 83). This gate has the form of a Toba Batak house for upper class families. Pospos points out in the text, however, that his family lived in a very simple house (not an ladat housen) and that families like his had too much to do earning a living to notice the scenic beauty of the Lake Toba region. Prapat, which actually is closer to Simelungun than Toba, 
does not figure at all in the narrative. Perhaps the book's production staff decided to include the photographs to make the memoir appear "more Batak" to a national buying public and readership that might think of Toba in such stereotypic terms as adat houses, lake scenery, funeral monuments, and so on.

Pospos's decision not to write his memoir in Toba Batak meant that it could be read throughout indonesia by members of other ethnic groups with differemt village adat.14 As noted, Pospos acknowledged this by inserting translations and explanations of the few Toba proverbs and adat phrases that he does use. Translations like these are deeply literate. No Toba fluent in the ethnic language would need explanations for the simple words and phrases Pospos uses; the translations are clearly directed toward an interethnic audience that "meets" the Toba Batak (or rather "Toba Batak ways") in books and other printed texts.

Preliterate Toba Batak village culture probably defined the human world as a Toba place (that is, the human place). Knowledge of outside ethnic groups must have been relatively limited for the individual villager, whose social world rarely extended into the neighboring Batak region; knowledge of outsiders was probably couched in stereotypes (Angkola as poisoners, for instance). The sort of reading and writing introduced by the colonial school system opened up the Toba world to other peoples. By the 1950s schoof texts and books, published by Balai Pustaka in particular, on other Indonesian cultures had enabled Batak school children to encounter in their reading other sorts of Indonesians, as well as Western Europeans, ancient peoples like the classical Greeks, and so on.

Some authors from other parts of the country, writing memoirs of their childhood, stress the interethnic and specifically educational possibilities of Indonesian-language texts more than Pospos does. His longest explanation of a Toba concept is a oneand-a-half page discussion of clan history (pp. 47-48) and most similar translations he offers are only one or two lines long. His careful explanation of Toba house architecture in Chapter 1 (see above, p. 70) is unusual for him. He does not even mention a number of extremely importam adat concepts, such as the relationship of spiritual benevolence and practical support existing between wife-givers and wife-takers. In contrast, the Rotinese author Minggus Manafe includes lengthy and detailed explanations of Rotinese ritual, costume, house architecture, marriages, funerals, and so on in his childhood memoir Aneka Kehidupan di Pulau Roti (Balai Pustaka, 1967). Manafe also includes frequent asides to alert the reader not to make the mistake of confusing Rotinese customs, or political units, with those in Java during its time of ancient kingdoms. Partly because of his unrelieved effort to translate Rotinese culture into terms the author feels will be intelligible to his multiethnic readers, Manafe's tone tends to be that of a schoolmaster. Pospos's prose is more straightfonward and his Toba world is allowed to make sense for the reader largely in its own terms. Similarty, Pospos's childhood is presented as an entity with its own meaning evident from the narrative of the book itself. Java is mentioned fleetingly as an island full of prestigious schools, but certainty does not serve as a cultural framework within which to measure and evaluate Toba. In fact, "Javanese culture" isn't mentioned at all. Similarh, Pospos does not use his position as an adult writer to second-guess the activities and thoughts of the child.

14. Pospos notes in his letter to me that some readers took the title of the book, "Me and Toba," to mean "Me, here, versus you, Toba, there." He writes that this overemphasizes his break with Toba when he moved to Java for further schooling. The separation was not so emphatic or sharp. 
One additional crucial aspect of print publishing is that it yields finished products. When the reader turns the last page of a book, the story is done. If he returns to the book later, the lines on the pages are the same as before, and atthough a reader's interpretations of a printed work can deepen, the printed pages themselves are fixed in space. They are only alterable through the major sociological effort (involving such people as editors, printers, distributors, and publicists) of bringing out a new edition of the book. ${ }^{15}$

Having foxed printed texts fosters the notion of having "finished lives," in which a published portrayal of a boy's childhood can be presented to the public as the complete, finished, ultimately distilled "truth" about that life. Toba oral culture never allowed such finality but instead stressed flexible views of the world and people, and welcomed the comments and additions of numerous orators, who all talked about the same thing but in different but supposedly corroborative ways. The egotism of a single "in (the writer) promoting his one finished version of his one life would, in fact, have been largely unthinkable in a Toba world before literacy and print publishing.

Nevertheless, the oral heritage of Toba does exert an important influence in shaping the text.

\section{Influences from Toba Oral Culture}

The author does not use such devices as formulaic opening and closing statements (patently derived from Batak adat oratory and used in a large number of other printed texts published from the 1930 s to the present), ${ }^{16}$ but other aspects of the book "speak" to the reader in an intimate, near-oral way.

Pospos makes much, for instance, of the sound possibilities of Indonesian, and goes beyond what the standard written language would demand as a minimum in terms of repetition and alliteration. This can be seen in the following passage about scary ghosts (pp. 42-43), translated in a footnote.

Rumahku hanja $1 \mathrm{~km}$ djauhnja dari sekolah, tapi sering pula aku tidur disekolah itu, karena aku takut pulang sendirian kerumah. Meskipun guruku mengatakan padaku, batwa tidak ada jin dan setan, tapi perkataannja itu kurang kupercayai. Malam-malam dikampung kami (kampung itu dikelilingi numpun bambu dan hampir semua kampung ditanah Batak demikian) sering terdengar suara orok menangis dari arah rumpun bambu itu. Itulah katamya suara homang (semacam jin), yang dapat melompat-lompat dengan tidak kelihatan. Pada suatu malam terdengar suara demikian dibelakang numah kami. Ibuku dengan beberapa gadis (biasanya selalu ada beberapa gadis kampung itu tidur dirumah kami, sejak rumah kami sebuah emper) pergi menghalau homang itu. Aku ditinggalkan mereka seorang diri menjaga rumah. Hari gelap waktu itu. Karena ditinggal sendirian itu, aku menjadi takut, gemetar sekujur badanku. Aku berpikir: "Baiklah rumah kututup rapat-rapat, supaya jin itu jangan masuk," tapi aku teringat, bahwa homang dapat berpindah-pindah dengan tidak kelihatan, jadi dapat juga masuk rumah dengan tidak ketahuan dari mana jalannya. Sebab itu kubuka saja pintu lebar-lebar dan aku berdiri bersandar ketiang pintu menanti mereka pulang, sambil mataku kupasang benar-benar melihat kekiri dan kekanan,

15. See Ong, Orality and Literacy, pp. 77-138 on this.

16. See the Toba Batak adat handbooks listed in note 6 . 
kebelakang dan kemuka, kalau-kalau jin itu melompat kedekatku. Badanku menggigil dan aku telah bersedia berteriak sekuat-kuatmya. Mujurlah tidak ada terjadi apa-apa. Ibuku dan gadis-gadis lain kudengar berteriak-teriak mengusir homang itu. Kudengar juga homang itu diam. Kepadaku diceritakan mereka, bahwa mereka mendengar bambu berderes-deres. Barangkali homang itu melompat-lompat lari, tapi sesuatu machluk tidak kelihatan oleh mereka, mungkin karena hari gelap. Didekat mereka aku telah biasa kembali dan pura-pura kuperlihatkan, bahwa aku tidak takut sama sekali. Aku malu menceritakan pengalamanku selama mereka menghalau homang itu. ${ }^{17}$

This paragraph lends itself easily to being read aloud. The repetitiveness of the passage, with language such as "bambu berderes-deres" and "homang itu melompatlompat lari" make it seem quite appropriate to a scary incident in the life of a little boy or the memory of such an incident in an indulgent adult. Although the book as a whole seems to have been written to be read silently from from to back, at the pace a reader himself determines, to appreciate the musical sound quality of passages like the one above they need to be read aloud. And the mamy $k u$ forms that appear in Pospos's lines make the narrative into a familiar sort of Indonesian, conjuring up the kind of shared intimate social community characteristic of the oral heritage.

But, note how in the same paragraph Pospos uses parenthetical phrases to add detail. This is a product of a convinced written style, in which the writer can "descend" temporarily from the main line of argument to add a fine detail, an extension of meaning, or a caveat, and then come back out of the parenthetical statement to retum to the original line of thought and the main sentence structure. Batak ritual oratory tends more toward aggregative accumulations of phrases (this and this and this and this and ... .) with eulogistic modifiers to add detail ("the beneficent

17. My house was only $1 \mathrm{~km}$. away from school, but I often slept over at school anyway, because I was afraid to go home by myself. Even though my teacher had said to me that there weren't any evil spirits and devils, I didn't quite believe what he said. In our village at night (our village was surrounded by clumps of bamboo and almost all villages in Batak land were like that) the voice of a baby crying could often be heard from the direction of the bamboo thicket. This it was said was the voice of the homang (a kind of spirit) which could jump about without being seen. One night such a voice was heard behind our house. My mother and several girls (some girls from the village ahways made a habit of sleeping at our house, since our house had a porch) went off to chase the homang away. They left me behind, by myself to guard the house. The night was dark then. Because I was left all alone, I became scared, trembling all over $m$ body. I thought: 'th's best that I close up the house really tight, so the spirit doesn't get in,' but I remembered that the homang could move about without being seen, and so could get into the house without anyone knowing the way he came. So I opened the door very wide and stood leaning against the door post waiting for them to get home, while my gaze veered from left to right, from back to front, in case the spirit should leap out at me. My body was shaking and I was all ready to yell out as loudly as I could. Luckily nothing at all happened. My mother and the other girls I heard shouting to chase the homang away. I also heard the homang just being quiet. They told me that they had heard the bamboo canes tapping against each other. Perhaps the homang had just leaped away, but they hadn't seen the creature, possibly because it was dark. Being close to them I returned to normal and pretended that I hadn't been scared at all. I was ashamed to tell them what had happened while they were off chasing the homang." 
wife-givers," "the all-wise raja"). No passages in Me and Toba, however, have entered so far into a literate style and paremthetical usage that they are impossible to read aloud and still make sense.

Batak adat orations start with formulaic phrases praising ancestors and the differem categories of kinspeople in the audience. These phrases also often evoke the protective blessings of such forebears and kin for the delivery of the speech itself, and for its target audience (the orator's newly married son, recently deceased grandmother, and so on). Speeches end with similarly comventionalized phrases, which also evoke the benevolent powers of supematural and assembled kin. Some phrases, like some introductory formulae, address malevolent spirits and wam them to stay away from the happy community of the oratory session. Early Batak print versions of turi-turian chanted myths would sometimes open and close with literate versions of these oral formulae. ${ }^{18}$ School primers, adat handbooks, and Batak-language fiction in the $1920 \mathrm{~s}$ and $30 \mathrm{~s}^{19}$ would sometimes also mimic the oratorical forms for beginning and ending important statements. Some of these statements appealed to the Christian or Muslim God, and almost all asked forgiveness in advance for any forthcoming mistakes in the text (a common apology used in adat oratory).

Me and Toba has none of this, unless one can count the reference to God in the book's last sentence ("Humankind can only make plans, but it is God who determines their outcome" [p. 132)). Pospos's narrative begins without amy preliminary scene setting, and each chapter ends with a comment, phrased in regular prose, on the last situation or event related. One possible nod in the direction of the oral heritage might be the very casualness of the first few sentences of the first chapter, which have something of the flavor of a friendly observation in passing with a friend. Cultures with restricted literacy sometimes employ this comversational style as a way to begin manuscripts. ${ }^{20}$ Pospos's literate world went far beyond manuscript technology but it is possible that he borrows the style of his opening lines from conversational speech.

Another important feature of the Me and Toba text, and one that definitely distances it from both ritual oratory and everyday Batak conversation, is its neartotal avoidance of inset verse passages (there is only one in the entire book, on p. 47). This is quite unusual for a Batak prose text published as earty as 1950. Mamy Toba and southern Batak novels, adat handbooks, and church circulars intemupt their prose passages every three or four pages to indent the text and insert verseform pantun (4-line verses) or adat oratory sayings. These passages are often set into italics and kept in the original Batak, in Romanized letters. If the text at hand is written in Indonesian, translations are sometimes included and the verses may be explained in expository form once the text has reverted to prose. In Bataklanguage texts, the indented verse passages are usually not explained any further

18. For a southern Batak example of this see Mangaradja Goenoeng Sorik Marapi's Turi-turian ni Raja Gorga di Langit dohot Raja Suasa di Portibi (first published 1938, reprinted 1957, but apparently first written down in 1914; no publisher listed in the book). For a Toba example in a printed rendition of a tarombo (clan genealogy) see the introduction (Hata Patoedjolo') of Mangaradja Salomo gelar Patoean Sarangnadiborngin's Tarombo Borbor-Morsada (Tarutung: Silindung Drukkerij, 1938).

19. Fiction in the Batak languages in this period was mostly an Angkola phenomenon, led by writers such as Soetan Pangoerabaan (Pane) and $M$. J. St. Hasoendoetan (Siregar). In my "Batak Literature of Modernization" (pp. 145-54) I mistakenly identified M. J. St. Hasoendoetan's novel Sitti Djaoerah as Soetan Pangoerabaan's Tolbok Haleon.

20. See Ong, Orality and Literacy, p. 125. 
but serve to summarize or illustrate a point just made in the prose text (similar to a technique of Batak oratory, where a good speaker will mention a kinship category, say, and then praise it with a string of verses or a mot juste from the large repertoire of adat sayings).

Pospos's avoidance of styles based in adat oratory for framing or punctuating his text removes it completely from the sacred realm of blessing speeches and eulogies. As a result, the narrative and the child's life within it gain a pedestrian though entertaining flavor.

\section{Audience}

Adat orations address a living assembly of kinspeople gathered in a close group around the speaker. Even today, they also address the world of ancestors (sometimes directly, as when an orator speaks at graveside or beside a tugu ancestor monument, and sometimes indirectly, when an ancestor's titles and mythical figures from early clan history are imvoked early in speeches as interested witnesses and protectors for the ritual). Some Batak printed texts from the colonial period address much this same range of persons, as well as an audience of "honored readers," although invocations of supernatural beings seem rare (perhaps because of church sponsorship of some of these texts). In addition, Batak fiction written from the 1920 s through the 1930 s often breaks the narrative to address the reader directly. ${ }^{21}$ in this convention the writer often instructs the reader about how he should apply the story's lessons to his own life, or how he should avoid the mistakes of the hapless characters. (Characters in Batak fiction generally lead hazardous ives, proceeding from one peril to the next.) After the "dear reader" injunctions, the author returns to his main narrative line and continues the story.

These conventions all spring from primary oral communications, where speaker and audience stand or sit within earshot of each other in an intimate community of shared sound and space. The "dear reader" style in print literature is an attempt to preserve this in books, albeit in much reduced social form.

Pospos's Me and Toba has little of this: no imvocation of a living audience of social intimates gathered around a speaker, no "honored reader," not even a "dear reader" in need of instruction. The memoir's audience is the socially disconnected group of Batak and non-Batak readers who happen to purchase or pick up the book anytime after it was published, even long after Pospos's death.

If the readers have no family-based reason to be interested in Pospos's childhood (one major folk rationale for listening to Batak oratory), and will get no specific moral instruction ${ }^{22}$ from the book (nor for that matter, many craftsmanlike ethnographic descriptions of Toba life), then they are left as an audience of readers, seeking knowledge of Indonesia under the Dutch presented in an appealing, lifestory form, or merely seeking entertainment. This affects Pospos's representation of his childhood. It is not the sort of exemplany life possible in forms of literacy more closely tied to oral worlds. Rather it emerges as a personalized account of

21. For a short discussion of this convention in Southern Batak fiction see my "Batak Literature of Modernization."

22. In his letter to me, the author notes that he did hope that his book would offer moral guidance to Toba parents in raising their children, but this is not apparent from reading the book's narrative itself. 
one specific man's early life, to be taken on its own terms and not as a type case of some general Toba or Indonesian passage to adulthood.

Ideas of Time and History

Me and Toba avoids specific calendrical dates and leaves the reader with the impression that the action takes place in a rather generalized late colonial period in Tapanuli sometime before the Japanese occupation. Despite this lack of calendar dates and the fact that the children in the stony do not coumt their ages in years, the memoir progresses through time, in a fairty linear fashion.

The memoir employs neither a cyclical time frame of the sort found in some oral traditions nor the timelessness of Toba origin myths. In those stories of clan origins, aboriginal migrations from the lake, and first settlements, the mythical beings like Si Raja Batak (the first human) exist in a kind of atemporal realm that is not so much "back then" in time in a linear way as it is "out there," just outside the lived present, surrounding it. This is the case even though Toba clan origin myths trace back history generation by generation from the present to Si Raja Batak. The ancestors are still "there," and can be evoked and contacted through special sorts of oratory. They are particularty there" in certain spots on the physical landscape, such as near graves and funeral monuments.

This type of nonlinear understanding of time is familiar from mamy mythic traditions in preliterate societies. Walter Ong suggests that this set of ideas may have something to do with communication form in cultures without reading and writing. 23 His point also relates to Batak adat and Batak concepts of adat's "ancientness" and validity.

After noting that clan genealogies and similar forms of folk history tend to be constantly fine-tuned to conform to present-day political alignments in oral cultures, Ong writes:

As has been seen in instances from modem Nigeria and Ghana (Goody and Watt (1968:31-4), ${ }^{24}$ in an oral economy of thought, matters from the past without any sort of present relevance commonly dropped into oblivion. Customary law, trimmed of material no longer of use, was automatically always up to date and thus youthful-a fact which, paradoxically, makes customany law seem inevitable and thus very old. . . Persons whose world view has been formed by high literacy need to remind themselves that in functionally oral cultures the past is not felt as an itemized terrain, peppered with verifiable and disputed "facts" or bits of information. It is the domain of the ancestors, a resonam source for reviewing awareness of present existence, which itself is not an itemized terrain either. . . .25

With literacy and the Dutch administrative interest in codifying local adat "systems" throughout Sumatra, Fexible and constanthy adjustable oral adat traditions were set down in prim in legalistic form. Canonized in this way for study and political manipulation by outsiders, they lost some of the quality of perpetual youthfut-

23. Ong, Orality and Literacy, pp. 96-101.

24. J. Goody and lan Watt, "The Consequences of Literacy, in Literacy in Traditional Societies, ed. Jack Goody (Cambridge: Cambridge University Press, 1968).

25. Ong, Orality and Literacy, p. 19. 
ness and relevance-within-ancientness that the oral adat had enjoyed. Literacy fostered the development of a notion of "anciemt adat" that actually did originate "back in time," at a point on a developmental line. Later additions to the adat or changes became "amendments" to this "older," "traditional" canon.

By 1950, when Pospos published his memoir, Batak adat had been subject to study and codification by European missionaries and Dutch civil servants for about ninety years. Since the 1920 s Toba Batak themselves had been publishing printed versions of their adat "folklore" under Dutch government and missionary auspices. Some of Pospos's reliance on ideas of developmental time may trace to this context.

\section{Forms of Knowledge}

For the most part, the topics with which Pospos deals are the forms of knowledge more associated with the schoolroom than the village ceremony.

He conveys this message in part by his method of framing passages about Toba ways." For instance, Chapter 7 begins with a reference to Toba origin myths but portrays these in such a way as to indicate both Pospos's understanding of time and his evaluation of Toba-language ritual speech about origin times:

According to the tales, Batak people are the descendants of Si Raja Batak. He was born from his mother Si Boru Deak Parujar, who was the child of a god, the highest god, Debata Mula Jadi Nabolon, born to forge the world. After the world was forged, he resided in Sianjurmulamula. This village became the home of Si Raja Batak too and was located on the slopes of Mount Pasukbuhit. This, it is said, was the origin land of the Batak and the Karo. (p. 47)

The use of "according to the tales" and in is said" distances the writer from the community that actually believed the origin myths. This inetorical style also relativizes the stories' importance within a "more sophisticated" world of school leaming and monotheistic belief. Pospos represents his childhood seff as being an urmilling churchgoer (until he got to MULO in Tanutung and discovered that church was a good place to watch girts). However, his view of Toba ritual and myth is generally executed from an implicith Christian perspective. Protestantism in longtime Christian Toba families (recall that the child's father is a simtua) had the effect of transforming Toba belief about the supermatural into Holklore and old stories "our ancestors told before they found out the truth about God and Jesus Christ" (in some areas this process is still ongoing).

If Toba-language myth is of less validity than the Christian framework within which it is placed, what about the healing and divination lore of village priests? Or Batak script writing, or village advice speeches? Other memoir writers like Manafe write about these forms of knowledge at length, with something of an antiquarian interest, but Pospos almost entirely neglects them. $h$ is as if village priests and orators were simply not presem in the child's life.

In sociological terms this may have been because Pospos came from a non-aristocratic family that was excluded from the esoteric ritual knowledge and oratory performances of the chiefs, but as a literary phenomenon the near-complete omission of the adat oratory and divination lore is quine unusual for a Batak-authored book on rural experience. By avoiding the oral adat world and concemtrating on schoofrooms, teachers, and famities' educational hopes for their children Pospos fosters several impressions in the reader. 
First is the idea that the school world exists as something separate from adat. Second is the sense that school knowledge (reading, writing, counting, Dutch, Malay) is not only a valid realm for children to apply themselves to but is the single most prestigious domain for ambitious and practical-minded children who wish to further their families' interests. Third is the fact that school is theoretically open to anyone who is bright. and hardworking, whereas adat knowledge is inherently elitist. Great adat orators gain their prestige and sometimes their oratorical prowess through lineage inheritance and possession of sacred objects such as heirloom weapons and barkbooks. Successful schoolchildren like Pospos can be the children of any social class (even the son of transiently employed men like Pospos's father). By learning the Batak script and then the Roman alphabet they can gain access to amy school text, and in fact to any book, tract, or newspaper. They can even get a job imparting their knowledge of reading and writing, whereas a respected and feared priest maintains his power and prestige by hoarding to himseff the secret lore of formulae and bark books.

\section{Content: Schools and Characters}

Obviously, the developmental thrust of the narrated childhood is structured around schools. In a somewhat superficial way it might be noted that the child's progress through the different levels of schools could be the colonial era equivalent of the Batak stages of life posited in the adat (from birth to naming ceremony, to adolescent rites of passage, to marriage and so on). However, for Pospos the importance of schools goes beyond this, and his linkage of childhood and schootrooms is itself a sensitive indicator of where Toba culture stood in relation to literacy in late colonial times.

In cultures without mass literacy and without elaborate social class systems children can usually acquire a workable knowledge of their spoken language and its main etiquette forms by the time they are between 7 and 10 years old. After that point they essentially have most of the communication knowledge they will need to function as adults. In cultures with widely accessible writing systems, however, long periods of conscious study are needed to acquire the code of adutthood: reading and writing. In cultures with advanced literacy such study takes place in schoolrooms separated from family homes. Time in school spent acquiring the arcane written knowledge of adults develops as a period that is inserted between infancy and social maturity. Growing up is no longer as automatic and effortless as learning one's spoken language; in school, the child must apply himself to puzzling texts, and possibly fail at the effort (and remain at a "lower level of development").

It is perhaps no accident that Pospos writes of his childhood in this way, as a time of tension and trial. Children sit in their classrooms and try to break the codes of their lessons. Sometimes they fail, and they feel shame. With the colonial school system splitting Toba culture into an oral Toba-language world and a print culture in a foreign language, individuals' perceptions of their own lives may have broken apart too, imto a Toba-language infancy at home, a literate, sophisticated adulthood spemt in paid positions, and a long period of arduous and oppressive schooling in between.

Toba culture and the Indonesia of 1950 provided Pospos with many human and human-like characters to choose from in presenting his childhood: mythic semihuman figures such as the clan founders; stereotypic persons such as "son-of-clan-X" or wife-receiver-of-clan-Y"; generalized "little boy" (there is a generic Toba term for littlest boy in the family); Toba as a type; "Christian Batak" as a type, or even Christian. Pospos did not use any of these. Instead, he peopled his memoir with 
distinct, named, individualized characters who were not interchangeable with others of their class. In fact, the child's father and mother run counter to the stereotypical adat. In the ideal, parents are loving people who maintain a good deal of close physical and emotional contact with their young children. (Parents nursing sons and daughters and holding them by the hand or in tight cloth baby slings on the back are recurrent images in Toba proverbs. The parent-infant relationship is stressed over the parent-older child association.) But this is the view of the oral adat speech. The printed memoir genre enables Pospos to imagine a distant mother and father, and even a child who hits his mother back when she strikes him (p. 32).

Pospos's childhood friends are also fairty individualized. It is true that few are assigned personal names (most are just "my friend from such and such a class in school'). Several of them are definitely type characters (a mother's brother's daughter he didn't take to, for instance). However, a number of children are outfitted with distinctive likes and dislikes, physical attributes, and school talents. It must be admitted that once the memoir's child gets to be MULO-age he portrays the groups of adolescent girls with whom he interacts as the teasing, quick-witted unmarried girls who are a familiar, generic type from adat oratory and Toba village social life in general.

The oral culture of myths, orations, and proverbs tends to deal in terms of type characters (daughter-of-clan-X) and stage-of-life characters (grandparent of first grandchild) whose generalized features eclipse any individual traits or personal names. Some Batak print literature continued to employ stereotyped persons of this sont long after writing had been introduced to Tapanuli. Pospos's creation of relatively individualized characters with sometimes unorthodox personality traits or actions is in the tradition of authors who imagine themselves as reflective critics of their own society, with their own life experiences and competencies that derive from sources outside, their home culture.

One of the most eloquent parts of the memoir is the semantic content of the title itself: $M e$ and Toba. Toba as a place and a way of human life is largely a phenomenon of multiethnic interaction and the Indonesian consciousness of the nation as a country of many peoples. "Me" as a subject is an almost scandalously modern phenomenon that probably would not have made moral sense in rural areas before widespread literacy. By concentrating on such new and unorthodox ideas the memoir deals in a gentle way with revolutionary ways of thinking about one's past life and the past in general. 